\title{
Examining the major contributors of ozone pollution in a rural area of the Yangtze River Delta region during harvest season
}

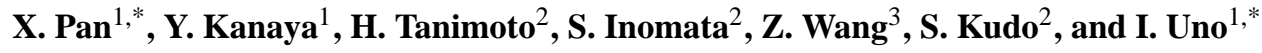 \\ ${ }^{1}$ Japan Agency for Marine-earth Science and Technology, Yokohama, Kanagawa prefecture, Japan \\ ${ }^{2}$ National Institute for Environmental Studies, Tsukuba, Ibaraki prefecture, Japan \\ ${ }^{3}$ State Key Laboratory of Atmospheric Boundary Layer Physics and Atmospheric Chemistry, Institute of Atmospheric \\ Physics, Chinese Academy of Sciences, Beijing, China \\ * now at: Research Institute for Applied Mechanics, Kyushu University, Fukuoka prefecture, Japan
}

Correspondence to: X. Pan (xlpanelf@riam.kyushu-u.ac.jp)

Received: 25 August 2014 - Published in Atmos. Chem. Phys. Discuss.: 9 December 2014

Revised: 17 April 2015 - Accepted: 27 April 2015 - Published: 4 June 2015

\begin{abstract}
Open biomass burning (OBB) emits significant amounts of non-methane hydrocarbons (NMHCs), and the mixing of OBB with urban plumes could exacerbate regional ozone $\left(\mathrm{O}_{3}\right)$ pollution. In the present study, an observational field campaign was performed in a rural area at the northern edge of the Yangtze River Delta region (YRDR) from 15 May to 24 June 2010, during intensive open burning of wheat residues. The net photochemical production rate of oxidant $\left(\mathrm{O}_{x}=\mathrm{O}_{3}+\mathrm{NO}_{2}\right)$ at the site was evaluated based on a box model (Regional Atmospheric Chemical Mechanism, Version 2) constrained by real-time ambient measurements (e.g., $\mathrm{O}_{3}$, volatile organic compounds (VOCs), $\mathrm{NO}_{x}$ $\left(\mathrm{NO}_{2}+\mathrm{NO}\right), J$ values). Our results showed that both in situ photochemistry and direct transport from urban areas in the YRDR were responsible for the high $\mathrm{O}_{x}$ concentration at the site. During an OBB-impact case, net photochemical production of $\mathrm{O}_{x}$ in the daytime was pronounced, with a $6 \mathrm{~h}$ averaged $\mathrm{O}_{x}$ production rate of $13 \pm 4 \mathrm{ppbv} \mathrm{h}^{-1}$ (maximum value of $21 \mathrm{ppbv} \mathrm{h}^{-1}$ at 12:00 CST). Photochemical $\mathrm{O}_{x}$ production changed from VOC-limited in the morning to $\mathrm{NO}_{x}$-limited in the afternoon due to the rapid photochemical consumption of $\mathrm{NO}_{x}$ during the day. A combined analysis with positive matrix factorization demonstrated that $\mathrm{O}_{3}$ pollution in the rural area of the YRDR was largely affected by urban emission, and OBB-related emissions also contributed to in situ photochemical production, particularly in the afternoon. Our study suggested that a joint effort in reducing both NMHCs (e.g., aromatics) and $\mathrm{NO}_{x}$ emissions in the urban area, as well as local OBB activities, may be effective in eliminating high- $\mathrm{O}_{3}$ pollution risk in the rural areas of the YRDR.
\end{abstract}

\section{Introduction}

Ozone $\left(\mathrm{O}_{3}\right)$ is a crucial component in the troposphere and plays a key role in the atmosphere's oxidation capacity, which strongly influences the lifetime of biogenic/anthropogenic compounds and their corresponding climate forcing effects (Sitch et al., 2007). High concentrations of tropospheric $\mathrm{O}_{3}$ are known to have serious detrimental environmental and health effects (e.g., crop yield reduction, human respiratory disorders) (Cape, 2008). In principle, the net production of $\mathrm{O}_{3}$ is due to the presence of peroxy radicals from the photochemical oxidation of non-methane hydrocarbons (NMHCs), which disturbs the $\mathrm{O}_{3}-\mathrm{NO}-\mathrm{NO}_{2}$ cycle, especially in urban areas where atmospheric loadings of NMHCs and the sum of $\mathrm{NO}_{2}+\mathrm{NO}\left(\mathrm{NO}_{x}\right)$ are pronounced.

In China, the Yangtze River Delta region (YRDR) is one of the most important economic centers and is responsible for $11-12 \%$ of total emission of NMHCs and $\mathrm{NO}_{x}$ in China (Zhang et al., 2009). These $\mathrm{O}_{3}$ precursor emissions have increased by $71 \%$ (NMHCs) and $89 \%\left(\mathrm{NO}_{x}\right)$ since 2000 (Kurokawa et al., 2013) due to rapid economic development in the region. Long-term observations have indicated that ground-level $\mathrm{O}_{3}$ pollution in the YRDR has been increasing at a rate of +0.52 ppbv year $^{-1}$ (Wang et al., 2009) and at a rate of $2.7 \%$ year $^{-1}$ in terms of variability in the daily maximum from 1991 to 2006 (Xu et al., 2008). Extreme $\mathrm{O}_{3}$ pollution (hourly averages reaching $286 \mathrm{ppbv}$ ) has been reported at a suburban site near the Beijing megacity due to an abundance of local $\mathrm{O}_{3}$ precursors (Wang et al., 2006).

Although open biomass burning (OBB) occurs sporadically and intensively, its impact on ambient $\mathrm{O}_{3}$ levels has 
been shown to be statistically evident. Onboard satellite observations have indicated that troposphere column $\mathrm{O}_{3}$ concentrations are enhanced by $10-25 \%$ in the downstream regions of fire (Ziemke et al., 2009). Such phenomena are supported by flight measurements (Takegawa et al., 2003), in which a clear positive correlation between $\mathrm{O}_{3}$ and carbon monoxide $(\mathrm{CO})$ measured in the OBB plume has been observed, implying that $\mathrm{O}_{3}$ was photochemically produced from its precursors emitted from OBB. A recent study showed that methyl vinyl ketone (MVK) and methylacrolein (MACR) (photo-oxidation products of isoprene), as well as isoprene, are present at significant levels in some OBB plumes, indicating that isoprene plays an essential role in $\mathrm{O}_{3}$ formation processes (Hornbrook et al., 2011). In China, large amounts of crop residue are burned directly in the field during harvest seasons, and such activities have remained intensive in the YRDR despite being legally banned by the government (Pan et al., 2011, 2013). Mixing of the OBB plume with anthropogenic pollutants (rich in NMHCs and $\mathrm{NO}_{x}$ ) emitted from urban areas may significantly boost $\mathrm{O}_{3}$ formation.

Recent analysis on the impact of $\mathrm{OBB}$ on regional $\mathrm{O}_{3}$ production has generally been based on model simulations by manipulating the emissions of $\mathrm{O}_{3}$ precursors from $\mathrm{OBB}$, and the results have been heavily dependent on the appropriateness and accuracy of OBB information (e.g., emission strength, geographical location, duration) (Yamaji et al., 2010). However, quantitative analysis of the contribution of OBB to in situ $\mathrm{O}_{3}$ production using field observations remains limited. In response to this limitation, a field measurement campaign was performed in a rural area of the YRDR from the middle of May to the end of June 2010. The $\mathrm{O}_{3}$ production rate and sensitivity were investigated using the Regional Atmospheric Chemistry Mechanism (RACM version 2), which was constrained by real-time measurements of $\mathrm{O}_{3}$ precursors, meteorological conditions, and $J$ values. Positive matrix factorization (PMF) was adopted in this study to identify the possible sources of NMHCs at the site. Besides diagnosis of the $\mathrm{O}_{3}$ production mechanism, this study provided recommendations to policy-makers to decrease the risk of high- $\mathrm{O}_{3}$ pollution in rural areas of the YRDR.

\section{Measurements}

Field measurements of $\mathrm{O}_{3}$ precursors were performed in a Science and Technology Zone (STZ) in a rural area of the northern YRDR $\left(32.25^{\circ} \mathrm{N}, 121.37^{\circ} \mathrm{E}\right.$; Rudong Town, Jiangsu Province, China) in June 2010. Anthropogenic emissions in the STZ were very limited. To the west of the site, there were acres of agriculture fields with few inhabitants, and to the south of the site, there were numerous small county towns (e.g., Qidong, latitude: $31.808^{\circ} \mathrm{N}$, longitude: $121.658^{\circ} \mathrm{E}$ ) and larger cities (population $>2$ million, e.g., Natong, latitude: $31.977^{\circ} \mathrm{N}$, longitude: $120.900^{\circ} \mathrm{E}$; Shang-

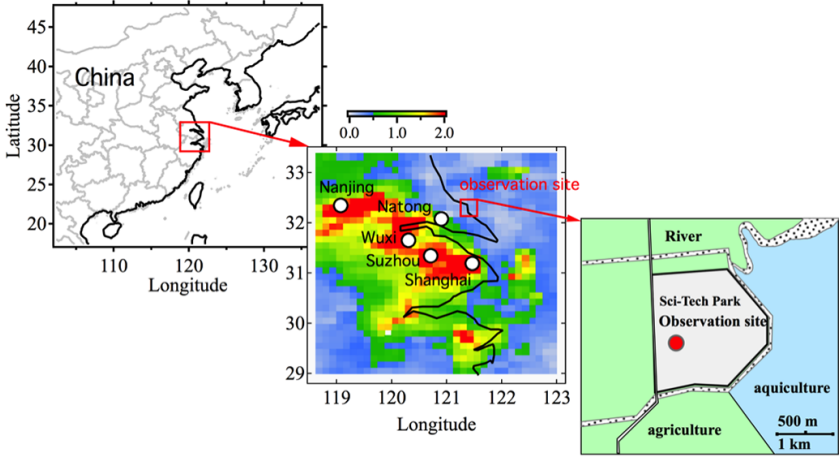

Figure 1. Geographic location of the observation site and the spatial distribution of monthly mean $\mathrm{NO}_{x}$ column density (unit: $\times 10^{6}$ molecule $\mathrm{cm}^{-2}$, the data were derived from OMI observations, DOMINO version 2.0, http://www.temis.nl/airpollution/no2. html) during the field campaign period and the surrounding environment at the site.

hai, latitude: $31.246^{\circ} \mathrm{N}$, longitude: $121.467^{\circ} \mathrm{E}$ ). Emissions from industrial/residential areas of these cities could be responsible for the observed $\mathrm{NO}_{x}$ and NMHCs at the site. The geographic information for the observation site is shown in Fig. 1. In this study, the mixing ratio of $\mathrm{O}_{3}$ was measured using a commercial $\mathrm{UV}$-absorption $\mathrm{O}_{3}$ analyzer (model 49c, time resolution: $1 \mathrm{~min}$; zero noise: $0.25 \mathrm{ppbv}$ with $1 \mathrm{~min}$ average; Thermo Scientific Inc.). The ambient $\mathrm{CO}$ mixing ratio was measured using a gas filter non-dispersive infrared $\mathrm{CO}$ gas analyzer (model $48 \mathrm{c}$, zero noise: $0.04 \mathrm{ppm}$ with $30 \mathrm{~s}$ average; Thermo Scientific Inc.). The zero point was periodically checked during the initial $20 \mathrm{~min}$ of each hour using purified air produced by a heated Pt catalyst (model 96; Thermo Electron Co.). Span calibrations were performed on site with standard span gas (2.03 ppmv, produced by Nissan-Tanaka Corp., Japan). Mixing ratios of $\mathrm{NO}$ and $\mathrm{NO}_{2}$ were detected using a commercial $\mathrm{NO}_{x}$ analyzer (model 42CTL; Thermo Scientific Inc.). We used two converters in parallel that were switched from one to the other, a molybdenum converter for measurements of $\mathrm{NO}_{y}$ (sum of $\mathrm{NO}_{x}, \mathrm{HNO}_{3}, \mathrm{~N}_{2} \mathrm{O}_{5}, \mathrm{PAN}$, etc.) and a photolytic converter for selective measurements of $\mathrm{NO}_{2}$. The precision of the instrument is $0.4 \mathrm{ppbv}$ with a zero noise of $0.2 \mathrm{ppbv}$ with a $1 \mathrm{~min}$ average. The instruments were placed in a temperature-controlled container and ambient air was drawn into the room through a $2.5 \mathrm{~m}$-long, $1 / 4$ inch Teflon tube.

A total of 15 NMHC species (see Table 1) were detected using online gas chromatography-flame ionization detection (GC-FID) and gas chromatography-mass spectrometry (GC-MS) at a time resolution of 1-2 h. During measurement, ambient air was first directed to a pre-concentration unit (GAS-30; DKK-TOA Corp., Ltd., Japan) with a sampling time of $10 \mathrm{~min}$. Valves and transfer lines were maintained at $80^{\circ} \mathrm{C}$ to minimize the loss of VOCs in samples, and the trapping tube was held at approximately $-78^{\circ} \mathrm{C}$ us- 
Table 1. Statistics on the mixing ratios of $\mathrm{NMVOC}$ species and $\mathrm{NO}_{2}$ (in unit of ppbv), and mass concentration of $\mathrm{BC}$ (in unit of $\mu \mathrm{g} \mathrm{m}^{-3}$ ) during the field campaign period.

\begin{tabular}{lrrrrrrr}
\hline Species & Average & SD & Max. & Min. & Median & 10th percentile & 90th percentile \\
\hline Propane & 1.2 & 2.2 & 4.9 & 0.01 & 0.5 & 0.14 & 2.5 \\
Propylene & 0.7 & 1.5 & 8.2 & 0.01 & 0.2 & 0.08 & 1.4 \\
$i$-Butane & 0.9 & 1.1 & 5.5 & 0.00 & 0.4 & 0.12 & 2.2 \\
$n$-Butane & 1.3 & 1.6 & 7.6 & 0.02 & 0.7 & 0.11 & 3.6 \\
$t$-2-Butene & 0.1 & 0.2 & 1.8 & 0.00 & 0.1 & 0.03 & 0.2 \\
1-Butene & 0.2 & 0.4 & 3.1 & 0.01 & 0.1 & 0.02 & 0.4 \\
$c$-2-Butene & 0.1 & 0.1 & 0.7 & 0.00 & 0.0 & 0.01 & 0.1 \\
$i$-Pentane & 0.8 & 0.7 & 4.0 & 0.09 & 0.6 & 0.25 & 1.6 \\
$n$-Pentane & 0.4 & 0.3 & 1.9 & 0.04 & 0.3 & 0.11 & 0.7 \\
Isoprene & 0.2 & 0.1 & 0.6 & 0.01 & 0.1 & 0.03 & 0.3 \\
Benzene & 1.0 & 0.9 & 4.4 & 0.06 & 0.7 & 0.19 & 2.4 \\
Toluene & 3.5 & 5.1 & 23.8 & 0.01 & 1.8 & 0.17 & 7.7 \\
Ethyl-benzene & 1.3 & 2.1 & 15.5 & 0.00 & 0.5 & 0.05 & 4.7 \\
$m-p$-Xylene & 0.7 & 1.3 & 5.9 & 0.00 & 0.2 & 0.03 & 2.8 \\
$o$-Xylene & 0.5 & 0.8 & 3.5 & 0.00 & 0.2 & 0.01 & 2.0 \\
Furan & 1.0 & 0.8 & 4.8 & 0.00 & 0.8 & 0.20 & 1.9 \\
Acetonitrile & 0.3 & 0.2 & 1.0 & 0.05 & 0.3 & 0.13 & 0.7 \\
Acetaldehyde & 3.4 & 2.6 & 15.8 & 0.07 & 2.7 & 0.86 & 7.6 \\
Acetone/Propanal & 4.2 & 2.6 & 13.4 & 0.53 & 3.6 & 1.51 & 8.3 \\
Acetic acid & 3.0 & 2.3 & 15.5 & 0.45 & 2.1 & 1.03 & 6.6 \\
MVK/MACR & 0.8 & 0.5 & 2.3 & 0.07 & 0.7 & 0.27 & 1.6 \\
MEK/Butanal & 1.1 & 1.1 & 5.4 & 0.09 & 0.7 & 0.30 & 2.6 \\
BC & 2.2 & 1.9 & 12.5 & 0.03 & 1.4 & 0.50 & 5.5 \\
NO 2 & 7.8 & 11.9 & 58.4 & 0.01 & 2.5 & 0.29 & 27.6 \\
\hline
\end{tabular}

ing liquid carbon dioxide. Calibration of the GC/FID/MS was performed using a gas standard of $1 \mathrm{ppm}$ containing 58 VOC components (PAMS-J58; Sumitomo Seika Chemicals Corp., Ltd., Japan). The detection limit of NMHCs by GC-MS was $0.002-0.005 \mathrm{ppbv}$ at a signal/noise ratio of 3 (Kudo et al., 2014). Six oxygenated volatile organics and acetonitrile (See Table 1) were also concurrently measured using a commercially available proton transfer reaction mass spectrometer (PTR-MS; Ionicon Analytik GmbH, Austria). The detection limit of PTR-MS was 0.01-0.08 ppbv, and the uncertainty of the measurements was estimated to be less than $15 \%$. The spectral actinic flux was measured using a single monochromator/photodiode array instrument (Meteorologie Consult Inc., Germany) with a wavelength ranging from 274 to $698 \mathrm{~nm}$. The uncertainty in the photolysis of $\mathrm{O}_{3}\left(J \mathrm{O}^{1} \mathrm{D}\right)$ for a similar instrument has been estimated to be $14 \%$. Chemical composition and the size distribution of aerosol particles were also measured during the field campaign. Detailed descriptions of these methods can be found in previous reports (Pan et al., 2012).

\section{Methodologies}

\subsection{Observation-based simulation of $\mathrm{O}_{3}$ production}

The simulation of $\mathrm{O}_{3}$ photochemistry was based on a photochemical box model, RACM version 2, which was recently released (Goliff et al., 2013). Compared with its previous version (RACM version 1) (Stockwell et al., 1997), the new version has expanded aromatic chemistry with a greater number of species, and additional and separate reaction schemes for benzene, $m$-xylene, $p$-xylene, and $o$-xylene chemistry. This mechanism employs 363 reactions and 120 species. In the calculations, $\mathrm{O}_{3}, \mathrm{NO}, \mathrm{NO}_{2}, \mathrm{SO}_{2}, \mathrm{CO}$, and $J$ values, as well as NMHC species, were processed into a data set with a time resolution of $10 \mathrm{~min}$. The missing data (between 13 and 17 June 2010) due to instrumental maintenance were linearly interpolated but not included in the analysis. Concentrations of all species at 00:00 CST were considered the initial condition, and the integration was conducted repeatedly with an integration step of $0.01 \mathrm{~s}$ five times on each day. Results of the last $24 \mathrm{~h}$ were used as the output of simulations after the stabilization of unmeasured species. The mixing ratio of NO was assumed to be $0.01 \mathrm{ppbv}$ when the observation was below the detection limit. $\mathrm{O}_{3}$ photochemistry during the daytime (06:00-18:00 CST) was manifested based on the constrained steady-state calculation. Since $\mathrm{NO}_{2}$ existed at high 
concentrations comparable to $\mathrm{O}_{3}$ at the observation site, the instantaneous net $\mathrm{O}_{x}\left(\mathrm{O}_{3}+\mathrm{NO}_{2}\right)$ production rate $\left(\mathrm{P}\left(\mathrm{O}_{x}\right)\right)$ was estimated by subtracting its loss $\left(\mathrm{D}\left(\mathrm{O}_{x}\right)\right)$ from the gross formation rate, $\mathrm{F}\left(\mathrm{O}_{x}\right)$. The formulae are given by the following:

$$
\begin{aligned}
& \mathrm{F}\left(\mathrm{O}_{x}\right)=k_{1}\left[\mathrm{HO}_{2}\right][\mathrm{NO}]+\Sigma k_{2 i}\left[\mathrm{RO}_{2}\right]_{i}[\mathrm{NO}] \phi_{i} \\
& \mathrm{D}\left(\mathrm{O}_{x}\right)=k_{3}\left[\mathrm{O}^{1}(\mathrm{D})\right]\left[\mathrm{H}_{2} \mathrm{O}\right]+k_{4}[\mathrm{OH}]\left[\mathrm{O}_{3}\right] \\
& +k_{5}\left[\mathrm{HO}_{2}\right]\left[\mathrm{O}_{3}\right]+\Sigma k_{6 j}\left[\mathrm{O}_{3}\right][\text { olefin }]_{j} \\
& +\Sigma k_{7}[\mathrm{OH}]\left[\mathrm{NO}_{2}\right] \\
& \mathrm{P}\left(\mathrm{O}_{x}\right)=\mathrm{F}\left(\mathrm{O}_{x}\right)-\mathrm{D}\left(\mathrm{O}_{x}\right),
\end{aligned}
$$

where $\mathrm{RO}_{2}$ represents organic peroxy radicals (e.g., $\mathrm{CH}_{3} \mathrm{O}_{2}$ ), $\phi$ represents yield of $\mathrm{NO}_{2}$ from the $\mathrm{RO}_{2}+\mathrm{NO}$ reactions, $[X]$ is the number density of species $X$, and $k_{1}-k_{7}$ are the reaction rate coefficients for the $[X][Y]$ reaction. $\mathrm{F}\left(\mathrm{O}_{x}\right), \mathrm{D}\left(\mathrm{O}_{x}\right)$, and $\mathrm{P}\left(\mathrm{O}_{x}\right)$ are calculated after the production and loss rates of the peroxy radicals are in balance. Although some unmeasured NMHC species impact the $\mathrm{P}\left(\mathrm{O}_{x}\right)$ calculations based on the RACM model, they do not change our major conclusions in the present study.

\subsection{PMF analysis}

Positive matrix factorization (PMF, version 5.0) is an advanced receptor model that analytically decomposes an $n \times m$ dimension matrix of observations into several factors $(p)$, the species profile $(f)$ of each source, and the amount of mass concentration $(g)$ by solving a constrained and weighted least-squares optimization equation, as follows:

$x_{i j}=\sum_{k=1}^{p} g_{i k} f_{k j}+e_{i j}$,

where $i$ and $j$ represent the number of samples and chemical species that were measured, respectively, and $e_{i j}$ is the residual for each sample/species. The PMF solution minimizes the object function $\mathrm{Q}$, as follows:

$Q=\sum_{i=1}^{n} \sum_{j=1}^{m}\left[e_{i j} / u_{i j}\right]^{2}$

where $u_{i j}$ is the uncertainty for each samples/species. This approach integrates non-negativity constraints into the computation to make the results physically meaningful and explainable. A detailed description of the model is available in the user's guide (http://www.epa.gov/heasd/research/pmf. html).

\subsection{Footprint analysis}

An ensemble simulation of a $72 \mathrm{~h}$ back trajectory of air masses was performed using the Hybrid Single Particle Lagrangian Integrated Trajectory model (HYSPLIT; http:

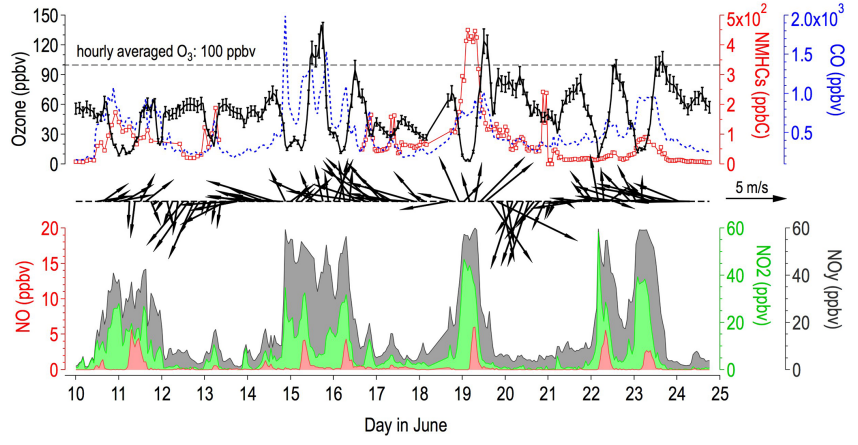

Figure 2. Time series of $\mathrm{O}_{3}, \mathrm{CO}, \mathrm{NMHCs}, \mathrm{NO}, \mathrm{NO}_{2}, \mathrm{NO}_{y}$ and wind information at the site during the field campaign.

//ready.arl.noaa.gov/HYSPLIT.php) by offsetting the meteorological data using a single meteorological grid point in the horizontal and 0.01 sigma units (approximately $250 \mathrm{~m}$ ) in the vertical. Input meteorological data were provided by the NCEP Global Data Assimilation System (GDAS) model with a grid resolution of $1^{\circ} \times 1^{\circ}$. To better review the impact of emissions on the surface layer, only the footprint region of the air mass was demonstrated. Here, the footprint region was determined as the grids in which the geographical height of the trajectory point was lower than the mixing height in the meteorological field. The footprint region was generally consistent with the spatial distribution of source-receptor relationships determined using the FLEXPART (http://flexpart.eu/) dispersive model (Pan et al., 2012).

\section{Results}

\subsection{Overview of observations}

Temporal variations of the mixing ratios of $\mathrm{O}_{3}$, NMHCs, $\mathrm{NO}_{x}, \mathrm{NO}_{y}, \mathrm{CO}$, and wind speed and direction are shown in Fig. 2. Statistics on the NMHC species are listed in Table 1. During the observation periods, five pollution episodes ( 10 to 12,14 to 17,18 to 20,22 , and 23 June in 2010) were clearly identified based on $\mathrm{NO}_{x}$ variations, and on 4 different days $\left(15,19,22\right.$ and 23 June, the hourly averaged $\mathrm{O}_{3}$ mixing ratio exceeded $100 \mathrm{ppbv}$ (dashed line as shown in Fig. 2). The highest $\mathrm{O}_{3}$ concentration (hourly mean: $140 \pm 3 \mathrm{ppbv}$ ) occurred at 17:00 CST on 15 June 2010. We found that the observation site was affected by the intensive open burning of crop residues in the surrounding agricultural according to the sharp increase in ambient $\mathrm{CO}$ levels. The hourly $\mathrm{CO}$ mixing ratio at 12:00 CST on 15 June was as high as $1309 \pm 91$ ppbv. $\mathrm{O}_{3}$ precursors flowed out from the urban areas to the south also contributed to the build-up of ambient $\mathrm{O}_{x}$ at the site, because obvious enhancements in the $\mathrm{NO}_{x}$ mixing ratio (hourly mean: $22 \pm 13$ ppbv) were observed with the prevailing southerly wind (SE-SW sector), and the ambient $\mathrm{O}_{3}$ mixing ratio decreased to almost zero due to titration 
reactions when the nitrogenous species were preferentially present in the early morning pollution days. The maximum concentration of NMHCs (hourly value: $443 \mathrm{ppbC}$ ) occurred at 07:00 CST on 19 June when the hourly averaged $\mathrm{NO}_{x}$ and $\mathrm{NO}_{y}$ mixing ratios were $42 \pm 2 \mathrm{ppbv}$ and $60 \pm 1 \mathrm{ppbv}$, respectively, and the hourly $\mathrm{O}_{3}$ mixing ratio was found to be $124 \pm 5 \mathrm{ppbv}$ at 12:00 CST due to strongly photochemical processes in the daytime. It was worth noting that the field campaign was just within the period of Shanghai World Expo 2010. Space-based observations demonstrated that tropospheric $\mathrm{NO}_{2}$ column loading and $\mathrm{CO}$ concentration at $700 \mathrm{hPa}$ decreased by 8 and $12 \%$ over the YRDR, compared with the past 3 years, probably due to short-term strict emission control measures (Hao et al., 2011). The variation in NMHC concentration during the Shanghai World Expo 2010 has not yet been reported. The effect of emission regulatory measures over the YRDR on the variability of $\mathrm{O}_{3}$ production potentials was out of the scope of this study, although tropospheric $\mathrm{O}_{3}$ precursors may be higher if no emission control policy is implemented.

\subsection{Diurnal pattern}

Figure 3 shows the average diurnal variations in $\mathrm{O}_{x}, \mathrm{CO}, \mathrm{NO}$, $\mathrm{NO}_{x}, \mathrm{NO}_{y}, \mathrm{NO}_{z}\left(=\mathrm{NO}_{y}-\mathrm{NO}_{x}\right), \mathrm{NO}_{x} / \mathrm{NO}_{y}$, and NMHCs for days when the maximum hourly averaged $\mathrm{O}_{x}$ concentration was greater than $100 \mathrm{ppbv}$ (red dotted lines) and those days when it was less than $100 \mathrm{ppbv}$ (blue dotted lines). The hourly averaged $\mathrm{O}_{x}$ in high- $\mathrm{O}_{3}$ pollution days showed a predominant single peak distribution with a daytime increase of $94 \mathrm{ppbv}$ (Fig. 3a), reflecting of a significant depletion of $\mathrm{O}_{3}$ at night and strong photochemical production of $\mathrm{O}_{3}$ during the daytime due to the presence of high concentrations of $\mathrm{O}_{3}$ precursors. In contrast, $\mathrm{O}_{x}$ levels on the low- $\mathrm{O}_{3}$ pollution days showed a moderate increase at noontime with a daytime increase of only 24 ppbv. Variation in NO (Fig. 3b) showed a prominent peak at 07:00 CST, especially on the high- $\mathrm{O}_{3}$ pollution days (maximum: $4.2 \pm 1.2 \mathrm{ppbv}$ ). On the low- $\mathrm{O}_{3}$ pollution days, the hourly averaged $\mathrm{NO}$ showed a weak peak $(1.1 \pm 1.5 \mathrm{ppbv})$. Diurnal variations in $\mathrm{NO}_{2}$ at the site showed evident increases at night with a predominant peak ( $39 \pm 18 \mathrm{ppbv})$ at 04:00 CST, distinct from the features (two peaks at 09:00 and 18:00 CST during rush hour) observed at the urban site of the Shanghai megacity. This implied that the $\mathrm{NO}_{x}$ was mostly transported to the observation site. A similar pattern was observed with the diurnal variation in $\mathrm{NO}_{y}$ (Fig. 3d) on high-O 3 pollution days, in that it showed a broader peak ( $54 \pm 6 \mathrm{ppbv}$ ) from 04:00-09:00 CST and gradually decreased to $26 \pm 3 \mathrm{ppbv}$ at 15:00 CST in the afternoon. As expected, $\mathrm{NO}_{z}$ showed an obviously unimodal distribution (Fig. 3f) with a maximum value of $33 \pm 10 \mathrm{ppb}$ at 12:00 CST when $\mathrm{O}_{3}$ photochemistry was proactive. We did not observe a clear increase in either $\mathrm{NO}_{y}$ or $\mathrm{NO}_{z}$ for the low- $\mathrm{O}_{3}$ pollution days.
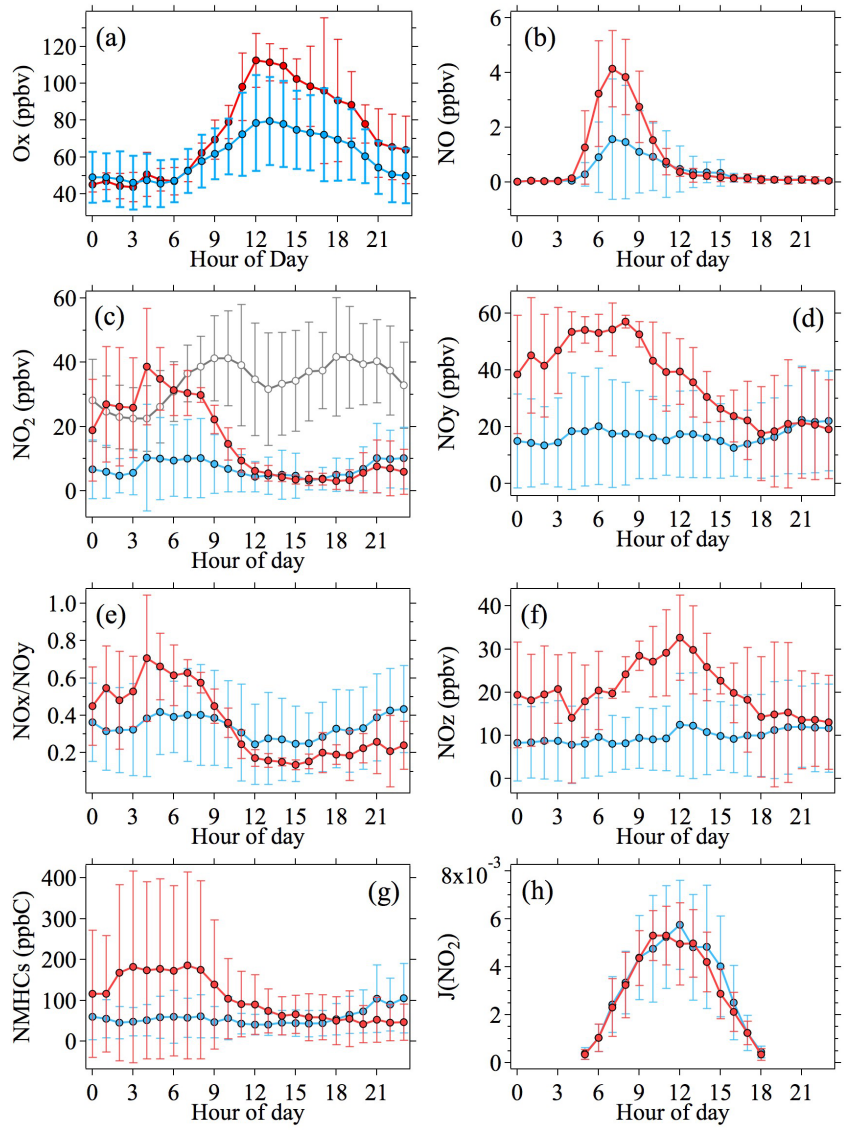

Figure 3. Diurnal variation in $\mathrm{O}_{x}, \mathrm{NO}, \mathrm{NO}_{2}, \mathrm{NO}_{y}, \mathrm{NO}_{x} / \mathrm{NO}_{y}$, $\mathrm{NO}_{z}, \mathrm{NMHCs}$, and $J\left(\mathrm{NO}_{2}\right)$ during the field campaign. The red and blue colors represent the averaged diurnal patterns for the high$\mathrm{O}_{3}$ pollution (hourly $\mathrm{O}_{3}$ mixing ratio $>100$ ppbv even only once in a day) and low- $\mathrm{O}_{3}$ pollution (hourly $\mathrm{O}_{3}$ mixing ratio $<100 \mathrm{ppbv}$ ) days, respectively. The gray line in (c) indicates the $\mathrm{NO}_{2}$ concentration in the downtown area of the Shanghai megacity.

Diurnal variation in the $\mathrm{NO}_{x} / \mathrm{NO}_{y}$ ratio is illustrated in Fig. 3e. In general, a higher $\mathrm{NO}_{x} / \mathrm{NO}_{y}$ ratio indicates that pollution plumes have a shorter photochemical age. In the present study, we found that the plumes on high- $\mathrm{O}_{3}$ pollution days were not photochemically aged $\left(\mathrm{NO}_{x} / \mathrm{NO}_{y}\right.$ ratio $>0.5$ ) when they were transported to the observation site in the morning, and they gradually became aged $\left(\mathrm{NO}_{x} / \mathrm{NO}_{y}=0.2\right)$ due to strong photochemical processes in the daytime. For low- $\mathrm{O}_{3}$ pollution days, the $\mathrm{NO}_{x} / \mathrm{NO}_{y}$ ratio did not vary significantly and had a mean of $0.34 \pm 0.1$.

As shown in Fig. 3g, the total NMHC concentration on the high- $\mathrm{O}_{3}$ pollution days and total hourly averaged NMHC concentration varied significantly (91-447 ppbC) in the early morning (00:00-06:00 CST), and it decreased gradually to $65 \pm 55 \mathrm{ppbC}$ in the afternoon (12:00-18:00 CST). On low$\mathrm{O}_{3}$ pollution days, the NMHC concentration was constantly low with a mean of $58 \pm 46 \mathrm{ppbC}$, implying that the contribution from the transport of urban emissions was less im- 
portant. Diurnal variations in $J\left(\mathrm{NO}_{2}\right)$ on the high- $\mathrm{O}_{3}$ and low- $\mathrm{O}_{3}$ pollution days during observation periods (Fig. 3h) showed nearly the same behavior, implying that the significant enhancement of $\mathrm{O}_{x}$ production during the high- $\mathrm{O}_{3}$ pollution period did not result from variations in solar radiation.

\subsection{Identification of source regions}

To identify the major source regions for $\mathrm{O}_{3}$ precursors, the color-shaded polar graph for $\mathrm{O}_{3}, \mathrm{NO}, \mathrm{NO}_{2}, \mathrm{NMHCs}$, $\mathrm{NO}_{x} / \mathrm{NO}_{y}$ and NMHCs $/ \mathrm{NO}_{x}$ is shown in Fig. 4. We found that a weak southerly wind $\left(\sim 3 \mathrm{~m} \mathrm{~s}^{-1}\right)$ was mostly accompanied by the occurrence of high- $\mathrm{O}_{3}$ pollution at the site (Fig. 4a), suggesting that in situ photochemistry was important, and the high- $\mathrm{O}_{3}$ concentration from the north and east was normally related to stronger winds $\left(>5 \mathrm{~m} \mathrm{~s}^{-1}\right)$, implying the potential contribution from direct transport. High concentrations of $\mathrm{NO}_{x}$ (Fig. 4b, c) and NMHCs (Fig. 4d) at the site were also related to emissions from the urban/industrial areas to the south. Figure $4 \mathrm{e}$ shows that air masses from the west and south normally were less photochemically processed, with an $\mathrm{NO}_{x} / \mathrm{NO}_{y}$ ratio larger than 0.5 , especially during the high- $\mathrm{O}_{3}$ pollution days when the $\mathrm{NO}_{x} / \mathrm{NO}_{y}$ ratio was greater than 0.8 .

The NMHCs / $\mathrm{NO}_{x}$ ratio partially reflected the characteristics of emission sources and corresponding $\mathrm{O}_{3}$ production potentials. The dependence of NMHCs $/ \mathrm{NO}_{x}$ on wind direction is shown in Fig. 4f. As demonstrated, the air masses from the north normally had high NMHCs / $\mathrm{NO}_{x}$ ratios with a mean of $50 \pm 44 \mathrm{ppbC} \mathrm{ppb}^{-1}$. Nevertheless, typically low NMHCs $/ \mathrm{NO}_{x}$ ratios $\left(8 \pm 7 \mathrm{ppbC} \mathrm{ppb}^{-1}\right.$ on average) were observed in the present study for plumes transported from the urban areas to the south. Ran et al. (2009) reported an average NMHCs $/ \mathrm{NO}_{x}$ ratio of $8 \mathrm{ppbC} \mathrm{ppb}^{-1}$ for pollution in the downtown area of the Shanghai megacity, generally consistent with our observations. For a detailed discussion on the dependence of $\mathrm{O}_{3}$ production on the NMHCs / $\mathrm{NO}_{x}$ ratio, see Sect. 5.3.

\section{Discussion}

\subsection{Net photochemical production rate of $\mathrm{O}_{x}$}

The net photochemical production of $\mathrm{O}_{x}\left(\mathrm{P}\left(\mathrm{O}_{x}\right)\right)$ during the field campaign was calculated based on Eqs. (1)-(3). Figure 5 shows the diurnal variations in $\mathrm{P}\left(\mathrm{O}_{x}\right)$ for three high- $\mathrm{O}_{3}$ pollution days. As shown in Fig. 5a and d, when the site experienced prevailing moderate southwest winds $\left(\sim 4 \mathrm{~m} \mathrm{~s}^{-1}\right)$ on 19 June 2010, the observed maximum $\mathrm{O}_{x}$ concentration was $128 \mathrm{ppbv}$ at 12:00 CST, with a daytime increase of $79 \mathrm{ppbv}$. $\mathrm{P}\left(\mathrm{O}_{x}\right)$ also peaked $\left(21 \mathrm{ppbv} \mathrm{h}^{-1}\right)$ at 12:00 CST with an accumulated photochemical production of $\mathrm{O}_{x}(06: 00-12: 00 \mathrm{CST})$ of $73 \mathrm{ppbv}$. This indicated that in situ photochemistry almost fully explained the buildup of $\mathrm{O}_{x}$ at the site in the morning. In the afternoon, the $\mathrm{O}_{x}$ concentration decreased quickly to
52 ppbv (at 17:00 CST) when it changed to a strong westerly wind $\left(\sim 6 \mathrm{~m} \mathrm{~s}^{-1}\right)$, and the total in situ photochemical production of $\mathrm{O}_{x}$ was only $27 \mathrm{ppbv}$, reflecting the importance of direct transport. Footprint calculations (Fig. 6f) indicated that $\mathrm{O}_{x}$ formation at the urban area to the south of the observation site had a significant contribution. Total $\mathrm{O}_{x}$ production was found to be $100 \mathrm{ppbv}$ on a daily basis, and the $6 \mathrm{~h}(09: 00-15: 00 \mathrm{CST})$ averaged $\mathrm{P}\left(\mathrm{O}_{x}\right)$ was $13 \pm 4 \mathrm{ppbv} \mathrm{h}^{-1}$, which was similar to the observations $\left(13 \mathrm{ppb} \mathrm{h}^{-1}\right)$ in central Tokyo areas during the summer (Kanaya et al., 2008). On 23 June (as shown in Fig. 5c and f), the daytime maximum $\mathrm{P}\left(\mathrm{O}_{x}\right)$ was found to be $19 \mathrm{ppbvh}^{-1}$ at 11:00 CST. The accumulated photochemical production of $\mathrm{O}_{x}(06: 00-11: 00 \mathrm{CST})$ at the site was $41 \mathrm{ppbv}$, similar to the observed increase of $\mathrm{O}_{x}$ (48 ppbv) during this period, which indicated that the buildup of $\mathrm{O}_{x}$ could be attributed to in situ photochemistry. During the afternoon, the wind direction shifted from south to east (the marine region) around 12:00 CST, and the wind speed increased from 2 to $6 \mathrm{~m} \mathrm{~s}^{-1}$. Correspondingly, the $\mathrm{P}\left(\mathrm{O}_{x}\right)$ decreased sharply from 19 to $5 \mathrm{ppbv} \mathrm{h}^{-1}$, and the ambient $\mathrm{O}_{x}$ concentration at the site continued to increase and finally exceeded $100 \mathrm{ppbv}$ at 15:00 CST. On the same day, the observed $\mathrm{O}_{x}$ concentration at night reached 80 ppbv. This suggested that the photochemically produced $\mathrm{O}_{3}$ in the YRDR during the daytime was preserved over the marine area and was transported directly to the observation site with an easterly sea breeze at night.

On the morning of 22 June 2010 (as shown in Fig. 5b and e), the site experienced prevailing southwesterly winds, and the accumulated photochemical production of $\mathrm{O}_{x}(06: 00-$ 13:00 CST) was only $14 \mathrm{ppbv}$, accounting for one-fourth of the observed daytime $\mathrm{O}_{x}$ concentration buildup ( $\left.60 \mathrm{ppbv}\right)$, reflecting the importance of the direct transport of $\mathrm{O}_{x}$.

\subsection{Dependence of $\mathrm{P}\left(\mathrm{O}_{x}\right)$ sensitivity on the source region}

The sensitivity of $\mathrm{P}\left(\mathrm{O}_{x}\right)$ to its precursor concentrations was investigated based on model simulations by artificially multiplying the $\mathrm{NO}_{x}$ concentration by factors of 0.5 and 2 , while the NMHC concentration was kept unchanged, or by multiplying the NMHC concentration by a factor of 0.5 , while the $\mathrm{NO}_{x}$ concentration remained unchanged. The sensitivity of the $\mathrm{P}\left(\mathrm{O}_{x}\right)$ on several $\mathrm{O}_{3}$ pollution cases and their corresponding footprint regions was determined using a back trajectory model (Fig. 6). As shown in Fig. 4, the emission characteristics of $\mathrm{O}_{3}$ precursors observed at the site differed for pollutants arising from different directions, resulting in distinct $\mathrm{O}_{x}$ production sensitivity. For the pollution that originated from the western inland area (Fig. 6a, b), $\mathrm{P}\left(\mathrm{O}_{x}\right)$ was very sensitive to variations in VOCs, and a decrease in $\mathrm{NO}_{x}$ led to an obvious increase in $\mathrm{P}\left(\mathrm{O}_{x}\right)$, even in the afternoon when $\mathrm{NO}_{x}$ had been significantly consumed, which suggested that $\mathrm{P}\left(\mathrm{O}_{x}\right)$ occurred in a typically VOC-limited regime. However, when the air masses originated from the north/coastal region 


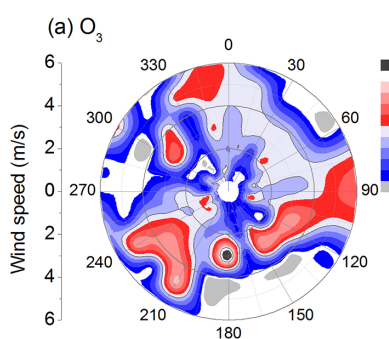

(d) $\mathrm{NMHCs}$

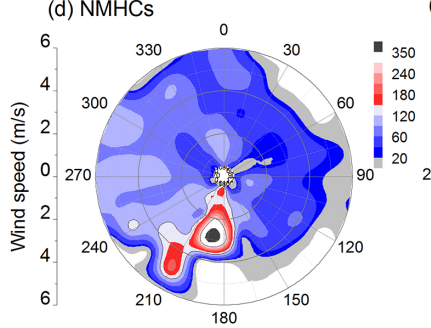

(b) $\mathrm{NO}$

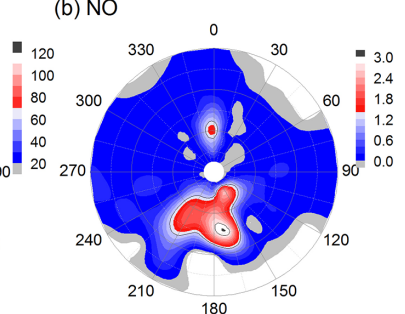

(e) NOx/NOy

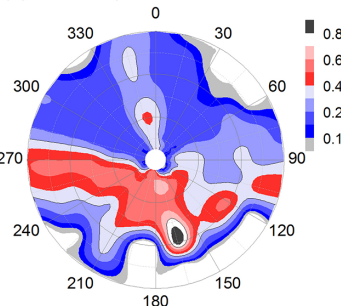

(c) $\mathrm{NO} 2$

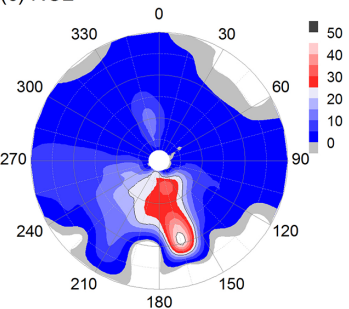

(f) $\mathrm{NMHCs} / \mathrm{NOx}$

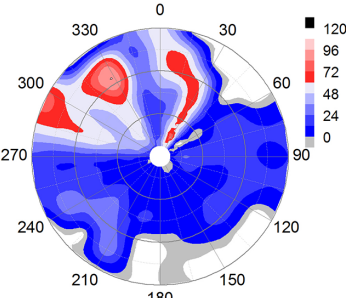

Figure 4. Dependence of the mixing ratios of (a) $\mathrm{O}_{3}$, (b) $\mathrm{NO}$, (C) $\mathrm{NO}_{2}$, (d) $\mathrm{NMHCs},(\mathbf{e}) \mathrm{NO}_{x} / \mathrm{NO}_{y}$, and (f) $\mathrm{NMHCs} \mathrm{NO}$ on wind direction and speed.

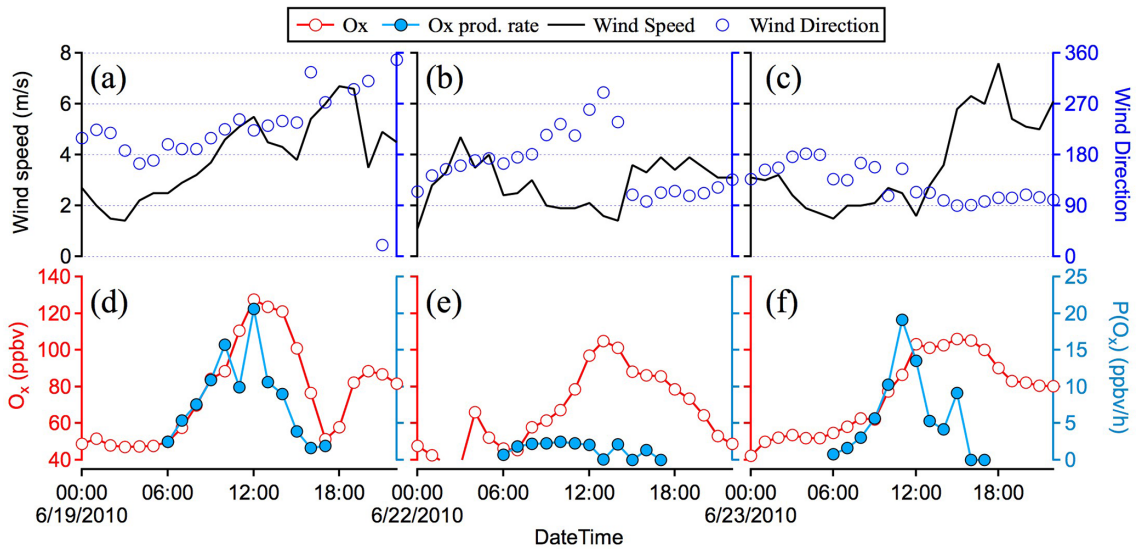

Figure 5. Diurnal variations in $\mathrm{O}_{x}$ concentration, $\mathrm{P}\left(\mathrm{O}_{x}\right)$, and wind speed and direction for three typical $\mathrm{O}_{3}$ pollution cases on 19 , 22, and 23 June during the field observation period.

(Fig. 6d), $\mathrm{P}\left(\mathrm{O}_{x}\right)$ was primarily controlled by ambient $\mathrm{NO}_{x}$ concentrations (Fig. 6c), as indicated by the extremely low $\mathrm{NO}_{x}$ concentration (average: $0.93 \mathrm{ppbv}$ ) and relatively high NMHC concentration (42.5 ppbv) during the daytime.

Most notably, we observed an obvious alteration in $\mathrm{P}\left(\mathrm{O}_{x}\right)$ sensitivity for the air mass transported from the south region (Fig. 6e and f). $\mathrm{P}\left(\mathrm{O}_{x}\right)$ on the morning of 19 June 2010, which was much more sensitive to the NMHC concentration than to $\mathrm{NO}_{x}$, and an increase in $\mathrm{NO}_{x}$ concentration resulted in a decrease in $\mathrm{P}\left(\mathrm{O}_{x}\right)$ (VOC-limited regime). In the afternoon, the $\mathrm{NO}_{x}$ mixing ratio decreased significantly from $21.7 \mathrm{ppbv}$ in the morning to $2.9 \mathrm{ppbv}$ in the afternoon due to photochemical processes in the atmosphere, and the $\mathrm{P}\left(\mathrm{O}_{x}\right)$ became $\mathrm{NO}_{x}$-limited, and a doubling of the $\mathrm{NO}_{x}$ concentration led to a clear increase in $\mathrm{P}\left(\mathrm{O}_{x}\right)$. Footprint analysis (Fig. 6f) indicated that the air masses were mostly stagnant over polluted regions in the YRDR, implying that anthropogenic pollution emission from urban areas was a determinant in the variation in $\mathrm{P}\left(\mathrm{O}_{x}\right)$.

\subsection{Isopleth diagram of $\mathrm{P}\left(\mathrm{O}_{x}\right)$}

To better evaluate the $\mathrm{P}\left(\mathrm{O}_{x}\right)$ sensitivity to NMHCs and $\mathrm{NO}_{x}$ concentrations at the site, a series of model runs were performed that artificially decreased and increased the $\mathrm{NO}_{x}$ and $\mathrm{NMHC}$ concentration to cover wide areas and simulate real atmospheric conditions, as described in Sect. 5.2. The mixing ratios of $\mathrm{O}_{3}, \mathrm{NO}_{x}$, and NMHCs, $J$ values, and meteorological data observed at 10:00 CST on 19 June were used as constraints. The dependence of the $\mathrm{P}\left(\mathrm{O}_{x}\right)$ on NMHCs and $\mathrm{NO}_{x}$ is shown in Fig. 7. The circles in the plot represent the calculated $\mathrm{P}\left(\mathrm{O}_{x}\right)$ and the gray dashed line indicates variations in $\mathrm{NO}_{x}$ during the day. The model predicted that the ridge of the $\mathrm{P}\left(\mathrm{O}_{x}\right)$ was associ- 

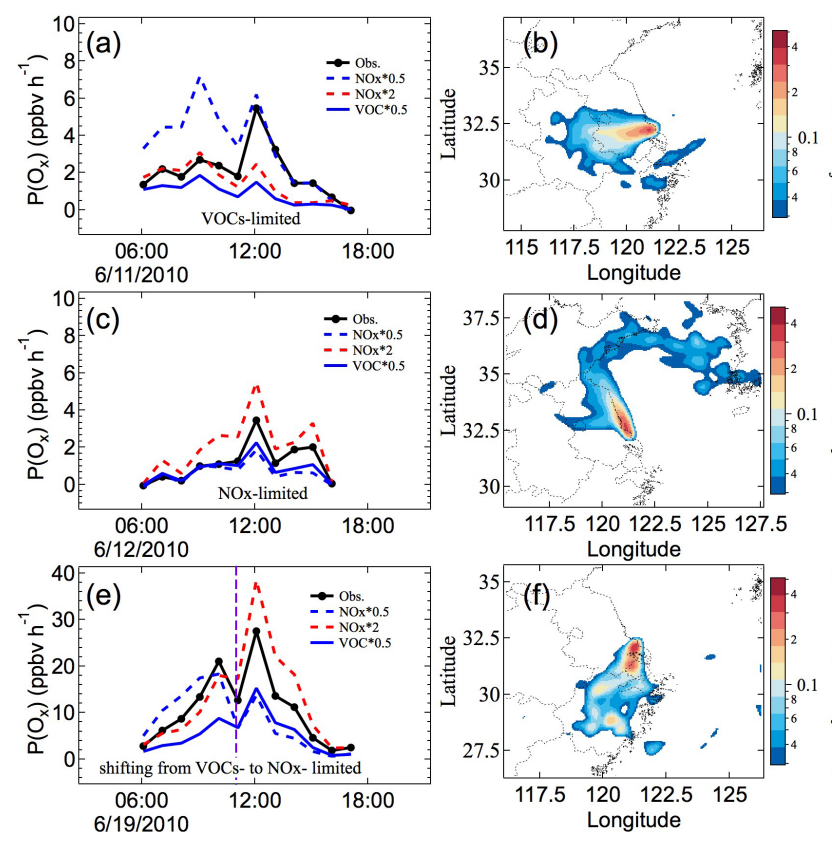

Figure 6. $\mathrm{O}_{x}$ production sensitivity of the air masses with different footprint regions. The left panel shows the variation in the production rate of $\mathrm{O}_{x}$ by artificial alteration of $\mathrm{NO}_{x}$ and VOCs; the right panel shows the number of trajectories that passed through the mixing layer for each case.

ated with an NMHCs $/ \mathrm{NO}_{x}$ ratio of $10-20 \mathrm{ppbCppb}^{-1}$, similar to the prediction of urban photochemistry in central Tokyo (Kanaya et al., 2008). In the morning, relatively low NMHCs $/ \mathrm{NO}_{x}$ ratios $\left(\sim 5 \mathrm{ppbC} \mathrm{ppbv}^{-1}\right)$ were found owing to a substantial amount of $\mathrm{NO}_{x}$, and $\mathrm{P}\left(\mathrm{O}_{x}\right)$ approached the predicted "ridge" region due to the preferential presence of hydroperoxyl $\left(\mathrm{HO}_{2}\right)$ and peroxy radicals based on model calculations. In the afternoon, the $\mathrm{NMHC} / \mathrm{NO}_{x}$ ratio increased evidently up to $30-50 \mathrm{ppbC} \mathrm{ppbv}^{-1}$ due to rapid $\mathrm{NO}_{x}$ photochemical loss. This tendency was generally consistent with the observation in the Shanghai urban area (Ran et al., 2009). Footprint analysis illustrated that the high concentration of NMHCs in the air mass was associated with urban emissions in the YRDR. $\mathrm{O}_{x}$ production on the morning of 23 June occurred in a typical VOClimited regime (NMHCs $/ \mathrm{NO}_{x}$ ratio: $\sim 1 \mathrm{ppbC} \mathrm{ppbv}^{-1}$ ), and it gradually shifted to a $\mathrm{NO}_{x}$-limited regime in the afternoon ( $\mathrm{NMHC} / \mathrm{NO}_{x}$ ratio: $21 \mathrm{ppbC} \mathrm{ppbv}^{-1}$ at 15:00 CST) due to a change in the wind direction.

\subsection{Contributions of different sources to in situ $\mathrm{P}\left(\mathrm{O}_{x}\right)$}

Source appointment of NMHCs observed during the field campaign was attempted based on the PMF calculation, as described in Sect. 3.2. The data matrix for PMF was 206 rows (samples) $\times 23$ columns (species). The uncertainty in NMHC concentrations was determined as the sum of $15 \%$ of the concentration and half of the detection limit (the same

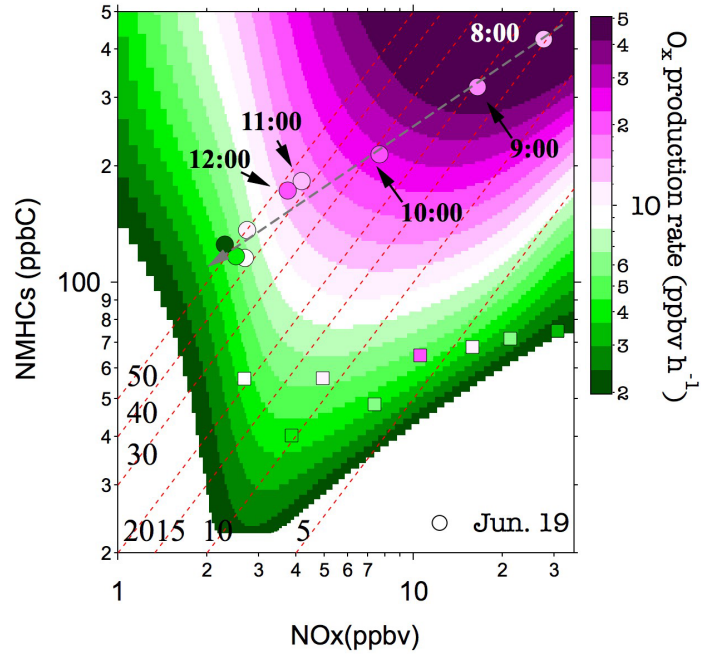

Figure 7. $\mathrm{O}_{3}$ production isopleth plot derived from RACM sensitivity simulations at the observation site. The gray dashed line indicates the diurnal variation of the ambient $\mathrm{NO}_{x}$ concentration on 19 June 2010. The red dotted lines represent the ratio of $\mathrm{NMHC} / \mathrm{NO}_{x}$.

as the descriptions in the PMF user's guide). Three potential factors were determined in this study. The contributions of the specified factor to each species are shown in the Supplement. Factor 1 showed an obvious diurnal variation and consisted of a large fraction of high-reactive species (e.g., $\mathrm{C}_{8}-\mathrm{C}_{9}$ aromatics, 1-butene) and $\mathrm{NO}_{2}$. Factor 2 did not have diurnal variability and had an abundance of low-weight alkanes and fewer fractions of high-reactive species and $\mathrm{NO}_{2}$. As reported previously (Yuan et al., 2012), NMHC photochemistry could lead to different time series for more and less reactive species, and PMF can detect these differences and attribute more or fewer reactive species to different factors, even though they originate from the same source. Therefore, we cannot identify the emission sources for these two factors. Instead, we attributed factors 1 and 2 to less-processed and more-processed air masses. Factor 3 was considered an OBB-related source due to the pronounced contribution of furan and acetonitrile with mass fractions of 64 and $50 \%$, respectively. This factor also accounted for $72 \%$ of total isoprene, $51 \%$ of MVK + MACR (oxidation production of isoprene), and $52 \%$ of acetic acid. As shown in previous studies (Kudo et al., 2014), factor 3 would retain the source characteristics, as the OBB occurred near the observation site.

The sensitivity of each source on $\mathrm{P}\left(\mathrm{O}_{x}\right)$ at the site was quantified as follows. The $\mathrm{NMHC}$ and $\mathrm{NO}_{x}$ concentrations of one selected factor were artificially increased by $10 \%$, while the concentration of $\mathrm{NMHCs}$ and $\mathrm{NO}_{x}$ for other factors remained unchanged. In such a situation, the total variation in $\mathrm{NMHC}$ and $\mathrm{NO}_{x}$ concentrations was normally within $5 \%$, guaranteeing that the RACM calculation could be well constrained. The variation in $\mathrm{P}\left(\mathrm{O}_{x}\right)$ due to changes in the NMHC 


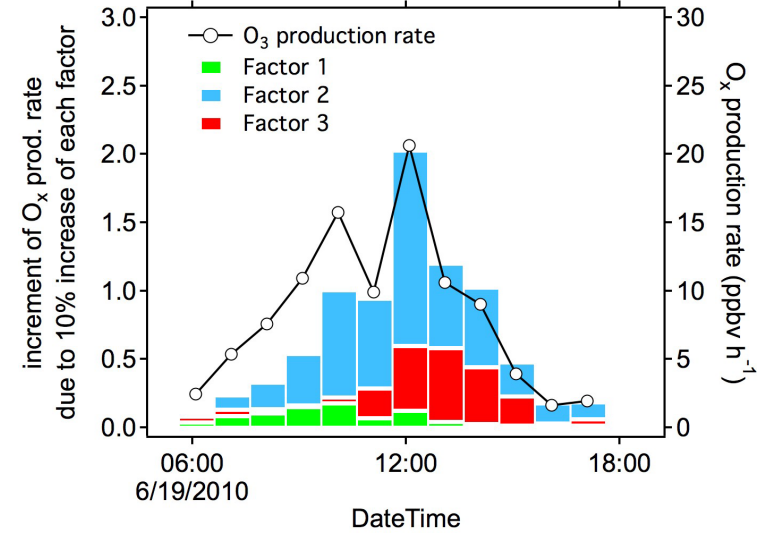

Figure 8. Diurnal variation in the sensitivity of each source to in situ $\mathrm{O}_{x}$ photochemical production and $\mathrm{P}\left(\mathrm{O}_{x}\right)$ on 19 June 2010.

and $\mathrm{NO}_{x}$ concentrations of selected factor was deemed the relative contribution of the factor to $\mathrm{O}_{x}$ formation. Here, we showed the relative importance of each factor on the in situ photochemical formation of $\mathrm{O}_{x}$ for a typical heavy $\mathrm{O}_{3}$ pollution case on 19 June 2010 (hourly averaged $\mathrm{O}_{3}$ concentration: $124 \pm 5 \mathrm{ppbv}$ and one minute value: $168 \mathrm{ppbv}$ at 12:00 CST). As shown in Fig. 8, the contribution of different sources to $\mathrm{O}_{x}$ production showed distinct variation patterns. Factor 2 was responsible for $60 \%$ (43 ppb) of the in situ photochemical production of $\mathrm{O}_{x}$ in the morning, followed by that of factor $1(23 \%, 17 \mathrm{ppb})$, and the OBB-related factor only accounted for $17 \%$ of the total $\mathrm{O}_{x}$ production. In the afternoon, the relative importance of OBB-related factors increased and was responsible for $34 \%$ (12 ppb) of the photochemical $\mathrm{O}_{x}$ production.

\subsection{Biogenic isoprene}

In the present study, mean mass concentrations of isoprene and MVK+MACR (photo-oxidation products of isoprene) at the site were $0.2 \pm 0.1 \mathrm{ppbv}$ and $0.8 \pm 0.6 \mathrm{ppb}$, respectively, with a mean MVK+MACR to isoprene ratio $([\mathrm{MVK}+\mathrm{MACR}] /$ isoprene) of 5.2. Biogenic sources (normally predominant at noon) were not mathematically resolved by the PMF calculation. Most of the isoprene was attributed to OBB sources and the rest was assigned to sources related to transport factors. First, the [MVK+MACR] / isoprene ratio was normally less than 0.4 in the biogenic sources-dominant environment (Montzka et al., 1993). Yuan et al. (2012) reported that the mass ratio of $[\mathrm{MVK}+\mathrm{MACR}] /$ isoprene was 0.3 for biogenic sources based on PMF analysis. In the present study, the [MVK+MACR] / isoprene ratio ranged from 3 to 25, suggesting that the impact of biogenic sources was not significant. Kudo et al. (2014) reported that observed normalized excess mixing ratios (NEMRs) of OVOCs increased with air mass age, suggesting that the isoprene may undergo further oxidization after being emitted. The upper limit of the $[\mathrm{MVK}+\mathrm{MACR}]$ / isoprene ratio was $\sim 30$ in this study. Third, the observation site was located adjacent to a large wheat field, and wheat plants emit small amounts of isoprene (Kesselmeier and Staudt, 1999); the diurnal variation in isoprene at the site did not show a pronounced enhancement at noontime (10:00-15:00 CST), and the $6 \mathrm{~h}$ averaged isoprene concentration was $0.19 \pm 0.16 \mathrm{ppbv}$. Based on these observations, we deemed that biogenic sources had limited impacts on in situ $\mathrm{O}_{x}$ production and were therefore neglected in the above discussion.

\subsection{Impact of aerosols on $O_{x}$ production}

The presence of particles reportedly can result in a significant heterogeneous losses of $\mathrm{HO}_{2}$ (Taketani et al., 2008), which plays a key role in peroxy radical equilibrium and $\mathrm{O}_{3}$ formation in the troposphere. The study at the mountain site in central East China indicated that ambient $\mathrm{HO}_{2}$ concentrations and corresponding $\mathrm{P}\left(\mathrm{O}_{x}\right)$ decreased due to the heterogeneous loss of $\mathrm{HO}_{2}$ (Kanaya et al., 2009). In the present study, the effect of a heterogeneous loss of $\mathrm{HO}_{2}$ on the $\mathrm{P}\left(\mathrm{O}_{x}\right)$ was investigated. The loss rate of $\mathrm{HO}_{2}$ was calculated using the Fuchs-Sutugin equation (Kanaya et al., 2009). The gas-phase diffusion coefficient of $\mathrm{HO}_{2}$ was assumed to be $0.247 \mathrm{~cm}^{2} \mathrm{~s}^{-1}$. The dependence on the uptake coefficient of $\mathrm{HO}_{2}$ on relative humidity (ranging from 0.2 to 0.35 ) was considered based on laboratory studies (Taketani et al., 2008). The number size distribution of particles (size bins: $0.3-0.5$, $0.5-0.7,0.7-1.0,1.0-2.0,2.0-5.0 \mu \mathrm{m}$ ) during the campaign was measured using a portable particle counter (model KR12A; RION Inc.). As a result, the estimated loss rate of $\mathrm{HO}_{2}$ ranged from $7 \times 10^{-3} \mathrm{~s}^{-1}$ to $0.05 \mathrm{~s}^{-1}$. The incorporation effect of $\mathrm{HO}_{2}$ loss into the RACM model calculation resulted in a reduction of $\mathrm{P}\left(\mathrm{O}_{x}\right)$ by $13 \%$ on average. Huang et al. (2011) reported that primary anthropogenic emissions of $\mathrm{PM}_{2.5}$ and $\mathrm{PM}_{10}$ in the YRDR were 1511 and $3116 \mathrm{Gg} \mathrm{yr}^{-1}$ in 2007 , respectively, accounting for 11 and $17 \%$ of the total emissions in China. This suggested that $\mathrm{O}_{3}$ photochemical production might have been depressed due to the presence of aerosol particles in the atmosphere. Our hypothesis was supported by a previous report (Gerasopoulos et al., 2013), which showed that $J \mathrm{O}^{1} \mathrm{D}$ decreased by $40 \%$ at a high solar zenith angle during high aerosol loading periods $(\mathrm{AOD}=0.5-0.7$ ). Presumably, ambient $\mathrm{O}_{3}$ concentrations would increase provided that particle emissions are significantly reduced, while $\mathrm{NO}_{x}$ and NMHCs emissions remain unchanged. Moreover, variability in meteorological conditions affects $\mathrm{O}_{3}$ production. For example, an increase in relative humidity could lead to a more rapid heterogeneous loss of $\mathrm{HO}_{2}$ on the wet surface of particles (Taketani et al., 2008). To summarize, accounting for the impact of aerosols is extremely important in reviewing and predicting $\mathrm{O}_{3}$ pollution in East Asia under the scenario of global warming. 


\section{Conclusions}

To investigate the impact of $\mathrm{OBB}$ on $\mathrm{O}_{3}$ pollution, a field campaign on $\mathrm{O}_{3}$ and its precursors was performed in a rural area of the YRDR during the harvest season in 2010. A photochemical box model (RACM version 2) was used to investigate the $\mathrm{O}_{x}$ production rate, controlling regime, and its possible contributors. Our study demonstrated that $\mathrm{O}_{x}$ pollution exacerbated when the site was subjected to both the OBB plumes and urban pollution in the YRDR. During a high$\mathrm{O}_{3}$ pollution period (19 June 2010), the diurnal variation in $\mathrm{O}_{x}$ production rates had a maximum value of $21 \mathrm{ppbv} \mathrm{h}^{-1}$, with an accumulated $\mathrm{O}_{x}$ production rate of $100 \mathrm{ppbv}$ on a daily basis. in situ photochemical production could almost fully explain the buildup of $\mathrm{O}_{x}$ in the morning at the site. Direct transport was also important for the ambient $\mathrm{O}_{x}$ level at the site, especially in the afternoon. $\mathrm{O}_{x}$ production sensitivity differed for the air masses arising from different directions due to distinct emission characteristics. When air masses originated from the urban/industrial areas to the south of the observation site, $\mathrm{O}_{x}$ production was NMHC-limited in the morning but became $\mathrm{NO}_{x}$-limited in the afternoon due to a significant depletion in $\mathrm{NO}_{x}$. According to PMF analysis, the contributions of three identified factors (less-processed, more-processed, and OBB-related sources) to in situ $\mathrm{O}_{x}$ production were evaluated. We found that less-processed and more-processed air masses were responsible for $83 \%$ of the photochemical production of $\mathrm{O}_{x}$ in the morning, and OBBrelated factors accounted for $34 \%$ of $\mathrm{O}_{x}$ production in the afternoon. Biogenic isoprene emissions were found to be less important for $\mathrm{O}_{x}$ production at the site during our study period. Our results implied that reductions in $\mathrm{NMHCs}, \mathrm{NO}_{x}$, and OBB control measures in the YRDR are important for reducing the risk of high- $\mathrm{O}_{3}$ pollution events.

\section{The Supplement related to this article is available online at doi:10.5194/acp-15-6101-2015-supplement.}

Acknowledgements. The authors thank the staff of the Rudong Municipal Environment Protection Bureau who provided us with assistance and facilitated the preparation and implementation of the field campaign. This work was supported by the Environment Research and Technology Development Fund (S-7, C-081, B-051) from the Ministry of the Environment, Japan.

Edited by: M. Shao

\section{References}

Cape, J.: Surface ozone concentrations and ecosystem health: Past trends and a guide to future projections, Sci. Total Environ., 400, 257-269, doi:10.1016/j.scitotenv.2008, 2008.

Goliff, W. S., Stockwell, W. R., and Lawson, C. V.: The regional atmospheric chemistry mechanism, version 2, Atmos. Environ., 68, 174-185, doi:10.1016/j.atmosenv.2012.11.038, 2013.

Hao, N., Valks, P., Loyola, D., Cheng, Y. F., and Zimmer, W.: Spacebased measurements of air quality during the World Expo 2010 in Shanghai, Environ. Res. Lett., 6, 044004, doi:10.1088/17489326/6/4/044004, 2011.

Hornbrook, R. S., Blake, D. R., Diskin, G. S., Fried, A., Fuelberg, H. E., Meinardi, S., Mikoviny, T., Richter, D., Sachse, G. W., Vay, S. A., Walega, J., Weibring, P., Weinheimer, A. J., Wiedinmyer, C., Wisthaler, A., Hills, A., Riemer, D. D., and Apel, E. C.: Observations of nonmethane organic compounds during ARCTAS - Part 1: Biomass burning emissions and plume enhancements, Atmos. Chem. Phys., 11, 11103-11130, doi:10.5194/acp11-11103-2011, 2011.

Kanaya, Y., Fukuda, M., Akimoto, H., Takegawa, N., Komazaki, Y., Yokouchi, Y., Koike, M., and Kondo, Y.: Urban photochemistry in central Tokyo: 2. Rates and regimes of oxidant (O3+ NO2) production, J. Geophys. Res.-Atmos., 113, D06301, doi:10.1029/2007JD008671, 2008.

Kanaya, Y., Pochanart, P., Liu, Y., Li, J., Tanimoto, H., Kato, S., Suthawaree, J., Inomata, S., Taketani, F., Okuzawa, K., Kawamura, K., Akimoto, H., and Wang, Z. F.: Rates and regimes of photochemical ozone production over Central East China in June 2006: a box model analysis using comprehensive measurements of ozone precursors, Atmos. Chem. Phys., 9, 7711-7723, doi:10.5194/acp-9-7711-2009, 2009.

Kesselmeier, J. and Staudt, M.: Biogenic volatile organic compounds (VOC): an overview on emission, physiology and ecology, J. Atmos. Chem., 33, 23-88, doi:10.1016/j.jqsrt.2014.08.003, 1999.

Kudo, S., Tanimoto, H., Inomata, S., Saito, S., Pan, X., Kanaya, Y., Taketani, F., Wang, Z., Chen, H., Dong, H., Zhang, M., and Yamaji, K.: Emissions of nonmethane volatile organic compounds from open crop residue burning in the Yangtze River Delta region, China, J. Geophys. Res.-Atmos., 119, JD021044, doi:10.1002/2013JD021044, 2014.

Kurokawa, J., Ohara, T., Morikawa, T., Hanayama, S., JanssensMaenhout, G., Fukui, T., Kawashima, K., and Akimoto, H.: Emissions of air pollutants and greenhouse gases over Asian regions during 2000-2008: Regional Emission inventory in ASia (REAS) version 2, Atmos. Chem. Phys., 13, 11019-11058, doi:10.5194/acp-13-11019-2013, 2013.

Montzka, S. A., Trainer, M., Goldan, P. D., Kuster, W. C., and Fehsenfeld, F. C.: Isoprene and Its Oxidation-Products, Methyl Vinyl Ketone and Methacrolein, in the Rural Troposphere, J. Geophys. Res.-Atmos., 98, 1101-1111, doi:10.1029/92JD02382, 1993.

Pan, X., Kanaya, Y., Wang, Z., Taketani, F., Tanimoto, H., Irie, H., Takashima, H., and Inomata, S.: Emission ratio of carbonaceous aerosols observed near crop residual burning sources in a rural area of the Yangtze River Delta Region, China, J. Geophys. Res.Atmos., 117, D22304, doi:10.1029/2012JD018357, 2012.

Pan, X. L., Kanaya, Y., Wang, Z. F., Liu, Y., Pochanart, P., Akimoto, H., Sun, Y. L., Dong, H. B., Li, J., Irie, H., and Takigawa, 
M.: Correlation of black carbon aerosol and carbon monoxide in the high-altitude environment of Mt. Huang in Eastern China, Atmos. Chem. Phys., 11, 9735-9747, doi:10.5194/acp-11-97352011, 2011.

Pan, X. L., Kanaya, Y., Wang, Z. F., Komazaki, Y., Taketani, F., Akimoto, H., and Pochanart, P.: Variations of carbonaceous aerosols from open crop residue burning with transport and its implication to estimate their lifetimes, Atmos. Environ., 74, 301-310, 2013.

Ran, L., Zhao, C., Geng, F., Tie, X., Tang, X., Peng, L., Zhou, G., Yu, Q., Xu, J., and Guenther, A.: Ozone photochemical production in urban Shanghai, China: Analysis based on ground level observations, J. Geophys. Res.-Atmos., 114, D15301, doi:10.1029/2008JD010752, 2009.

Sitch, S., Cox, P., Collins, W., and Huntingford, C.: Indirect radiative forcing of climate change through ozone effects on the landcarbon sink, Nature. 448, 791-794, 2007.

Stockwell, W. R., Kirchner, F., Kuhn, M., and Seefeld, S.: A new mechanism for regional atmospheric chemistry modeling, J. Geophys. Res., 102, 25847-25879, 1997.

Takegawa, N., Kondo, Y., Ko, M., Koike, M., Kita, K., Blake, D., Hu, W., Scott, C., Kawakami, S., and Miyazaki, Y.: Photochemical production of $\mathrm{O} 3$ in biomass burning plumes in the boundary layer over northern Australia, Geophys. Res. Lett., 30, 1500, doi:10.1029/2003GL017017, 2003.

Taketani, F., Kanaya, Y., and Akimoto, H.: Kinetics of heterogeneous reactions of $\mathrm{HO} 2$ radical at ambient concentration levels with (NH4) $2 \mathrm{SO} 4$ and $\mathrm{NaCl}$ aerosol particles, J. Phys. Chem. A, 112, 2370-2377, 2008.

Wang, T., Ding, A., Gao, J., and Wu, W. S.: Strong ozone production in urban plumes from Beijing, China, Geophys. Res. Lett., 33, L21806, doi:10.1029/2006GL027689, 2006.
Wang, T., Wei, X. L., Ding, A. J., Poon, C. N., Lam, K. S., Li, Y. S., Chan, L. Y., and Anson, M.: Increasing surface ozone concentrations in the background atmosphere of Southern China, 19942007, Atmos. Chem. Phys., 9, 6217-6227, doi:10.5194/acp-96217-2009, 2009.

Xu, X., Lin, W., Wang, T., Yan, P., Tang, J., Meng, Z., and Wang, Y.: Long-term trend of surface ozone at a regional background station in eastern China 1991-2006: enhanced variability, Atmos. Chem. Phys., 8, 2595-2607, doi:10.5194/acp-8-2595-2008, 2008.

Yamaji, K., Li, J., Uno, I., Kanaya, Y., Irie, H., Takigawa, M., Komazaki, Y., Pochanart, P., Liu, Y., Tanimoto, H., Ohara, T., Yan, X., Wang, Z., and Akimoto, H.: Impact of open crop residual burning on air quality over Central Eastern China during the Mount Tai Experiment 2006 (MTX2006), Atmos. Chem. Phys., 10, 7353-7368, doi:10.5194/acp-10-7353-2010, 2010

Yuan, B., Shao, M., Gouw, J., Parrish, D. D., Lu, S., Wang, M., Zeng, L., Zhang, Q., Song, Y., and Zhang, J.: Volatile organic compounds (VOCs) in urban air: How chemistry affects the interpretation of positive matrix factorization (PMF) analysis, J. Geophys. Res.-Atmos., 117, D24302, doi:10.1029/2012JD018236, 2012.

Zhang, Q., Streets, D. G., Carmichael, G. R., He, K. B., Huo, H., Kannari, A., Klimont, Z., Park, I. S., Reddy, S., Fu, J. S., Chen, D., Duan, L., Lei, Y., Wang, L. T., and Yao, Z. L.: Asian emissions in 2006 for the NASA INTEX-B mission, Atmos. Chem. Phys., 9, 5131-5153, doi:10.5194/acp-9-5131-2009, 2009.

Ziemke, J., Chandra, S., Duncan, B., Schoeberl, M., Torres, O., Damon, M., and Bhartia, P.: Recent biomass burning in the tropics and related changes in tropospheric ozone, Geophys. Res. Lett., 36, L15819, doi:10.1029/2009GL039303, 2009. 